\title{
ADVERTISING DIVERSITY
}





\title{
ADVERTISING DIVERSITY
}

Ad Agencies and the Creation of Asian American Consumers

\author{
SHALINI SHANKAR
}

DUKE UNIVERSITY PRESS

Durham \& London

2015 
(C) 2015 Duke University Press

All rights reserved

Printed in the United States of America on acid-free paper @

Typeset in Chaparral and Myriad by Tseng Information Systems, Inc.

Library of Congress Cataloging-in-Publication Data Shankar, Shalini, 1972-

Advertising diversity : ad agencies and the creation of Asian American consumers / Shalini Shankar.

pages $\mathrm{cm}$

Includes bibliographical references and index. ISBN 978-o-8223-5864-o (hardcover : alk. paper) ISBN 978-o-8223-5877-o (pbk. : alk. paper) ISBN 978-o-8223-7561-6 (e-book)

1. Advertising-Social aspects-United States.

2. Asian American consumers - United States.

3. Asian Americans - Race identity-United States. 4. Stereotypes (Social psychology) in advertising-United States. 5. Advertising agencies-United States. 6. Minorities in advertising-United States. I. Title.

HF5813.U6S53 2015

$659.1^{\prime} 042-d c 23 \quad 2014040371$

Cover art: Illustration based on a photo by the author. 
For Roshan and Anisha 
